\title{
Axiological Study Towards the Law Number 18/2019 about Pesantren
}

\author{
Muh Luthfi Hakim* \& A. Habiburrohman Aksa \\ Institut Pesantren Mathali'ul Falah Pati \\ *Corresponding Author: hakim@ipmafa.ac.id
}

\begin{abstract}
This study aims to analyse the law of pesantren axiologically as well as the response of the top academic pro-counter that appears on the legalize of pesantren's law. This research is normative legal research that is the object of study focused on Law Number 18/2019 about Pesantren. The approach that the authors used is the conceptual approach, this approach aims to find the intent and purpose of such legislation. The data collection method is done by using the method of documentation or library materials, then the data is analysed by how to describe and perform the axiological analysis. The results of this study are: First, in the axiological study, the legalize of pesantren's law provided many benefits in the form of recognition of equality for students who graduated from pesantren, in recognition of diversity about learning model in pesantren, the governance of independent pesantren as well as recognition of diversity about models and learning methods in pesantren. Second, the emergence of pesantren can provide many benefits for pesantren institution, then the charges which consider that pesantren's law is government intervention towards the pesantren cannot be justified.
\end{abstract}

Keywords: Axiological Study, Pesantren's Law, Law Number 18/2019

\section{Introduction}

The issuance of Law Number 18/2019 about Pesantren (here in after known as pesantren's law) bring a fresh breeze to the existence of the pesantren as an institution. The existence of pesantren in its function as the organizer of religious education of Islam and also the development of society indeed has not got the recognition of proportionate share of the government, at least until some regulatory laws invitation about pesantren and Islamic education, and the year 2019 is the final year when the pesantren's law was passed by the President. Those laws provide the legal certainty that is clearly against the legality of pesantren in Indonesia.

The pesantren, as delivered by Kyai Sahal serves not only as institutions of education and religious social institutions, but also has a central role in the 
development of society. But in reality, the function of the latter has not been done by pesantren for institutional and not equipped with the vision of a measured (Mahfudh, 1999), or at least not many pesantren institutions that do community development activities. Pesantren's law is also formulated by function relatively in the same way, they are spelled out in article 4 where the scope of pesantren function covering the fields of education, propaganda, and the implementation of community empowerment.

In the study of historical pesantren contribution as institutions of Islamic education cannot be separated from map of historical process of education development in Indonesia as a whole, especially in the moral education which later crowded so-called "character education". In fact, the pesantren also play a role in history of Indonesian independence and became main witness of the spread of Islam in archipelago.

The reality that pesantren become an important part that cannot be separated in developing a civilization nation of Indonesia is a necessity. It is evident that since the kingdom of Islam in Aceh at the first centuries of the Hegira, then continued in the era of Walisongo until the beginning of the 20th century many religious leaders and scholars became the forerunner appears as a new village. Islamic traditional education institution has evolved, particularly in Java-Madura for centuries. Maulana Malik Ibrahim (died in 1419 in Gresik, East Java), the Spiritual father of Walisongo, in a society of students of Java is seen as a great tradition of pesantren in Java. As a traditional Islamic education, pesantren has a great influence on the spread of Islam in Java, those things make the institution of Islamic empire has an important role for the spread of Islam up to the corners of villages. In order to focus on Islamization in Indonesia, pesantren has five basic elements, namely the cottage, the mosque, the students, the teaching of the classic books and scholars (Dhofier, 2011).

Hoping that the pesantren developers have the legality of law in line with magnitude of contribution that has been done. Government recognition of the existence of pesantren experience has significant developments from time to time. It is evident from the existence of some laws and regulations that already exist, which is then strengthened by the legalize of the legislation of pesantren at the 2019 . Pesantren's law become a legal law for pesantren to get the opportunity and recognition that equal with formal education beyond pesantren. 
Responsibility in the process of pesantren development is not only from the inside of pesantren itself, government as stakeholders also have a responsibility that is not less important. Improvement and development of the role as well as pesantren in the millennial era is a part in order to realize national education development goals and national development of the country in general. Especially in the field of characters building that have been experiencing a moral crisis and a crisis of identity (Setyawan, 2019).

Before the pesantren' law was passed, Rozin and Tutik stated that partiality of country against the pesantren can already be felt by the pesantren since the legalize of (PMA Number 18 of the year 2014 about Muadalah Unit Education, 2014) at

Pesantren and (PMA Number 71 of the year 2015 about Ma'had Aly, 2015). In the regulation, there are two important things about the partisanship of the state against pesantren. First, the government gives authority to any pesantren to organize the education system itself and independently. Second, the government, through the regulation provide for recognition of $M u^{\prime}$ adalah pesantren diplomas without going through the process of the exam as the national standard curriculum (Ghofarrozin \& Janah, 2021).

However, in this journey of pesantren's law is not separated from the pro-cons of various parties, both internal pesantren or from the external. Pro-counter approval of pesantren's law that most stands out is the cross talk which occurs between the biggest Islamic organization community (organisasi masyarakat/ormas) in Indonesia. Two of these organizations is Nahdlatul Ulamat (NU) and Muhammadiyah. NU in this case is the most intense push the government to immediately passed a pesantren's law. While PP Muhammadiyah representing other 10 organizations requested to postpone and re-examine the pesantren's law before actually passed. In addition to the Muhammadiyah Islamic organizations such other Aisyiyah, Persatuan Tarbiyah Islamiyah (PERTI), Persatuan Islam (PERSIS), Dewan Dakwah Islamiyah (DDI), Nahdlatul Wathan (NW) is a row name, which also had requested a delay in the ratification of pesantren's law planning (Ghofarrozin \& Janah, 2021).

Not stopping there, pro-cons has not been fully completed after the law was passed. This is motivated by lack of understanding of the intent and purpose of why pesantren's law need to be realized. To find out more about the intent and purpose 
of the existence of pesantren's law, this study will focus on a discussion of how the study of axiology of pesantren's law. Thus, it will be known more in why pesantren's law is important to be realized in Indonesia, so that the pro-cons that happen addressed objectively.

Axiology is a branch of philosophy that talk about the theory of value or usefulness. Jujun S. Suriasumantri define axiology as a theory of value that is related to the usefulness of the knowledge acquired, then be used in a variety of activities that have the benefits or usefulness of implementation and the role of knowledge (Suriasumantri, 2005). In connection with the discussion of the pesantren's law, the axiological study meant to analyse the use and benefits over ratification of law itself, including what goals will be achieved, and why the publication of pesantren legislation is necessary.

The study of this axiology done to give the response to the pro-cons from various parties, internal or external. By knowing the intent and purpose of the establishment of pesantren's law through axiological analysis, a pesantren as the most interested part in can be the right response to the presence of regulations that are intended for an Islamic educational institution, the oldest. In addition, the attitude of proportional pesantren institution in accepting this regulation will depend on how the understanding of pesantren parties toward the intent and purpose as well as written in pesantren's law.

Similar to another research about a review of pesantren legislation for example, research conducted by Maulana Arif Setiawan, with the main topic about "Law of pesantren: local genius and state intervention towards the pesantren". Maulana Arif Setiawan argues that the emergence of pesantren law about position of pesantren institution become increasingly clear. Nevertheless, pesantren legislation according to governments interventions are too far into the "deepest part" of pesantren (Setyawan, 2019), so the law of pesantren not yet fully accepted view of pesantren known as Islamic education institute that autonomously develop and innovate independently of the aspects of curriculum, administration and so on.

Criticism of pesantren legislation is not completely right. For example, if you look at some of the articles in the legislation to provide flexibility for the institution of pesantren to organize the teaching-learning activities independently with its own curriculum. Article 2, for example, mentions that principles of pesantren 
implementation is self-reliance (Law Number 18/2019, 2019). What is meant by the principle of self-reliance, which is the pesantren is done by optimizing internal resources from itself. Further pesantren has freedom to do all forms of organization of institution, curriculum, funding, and so on. As written in article 16 about the law of pesantren which expressly explain that pesantren held the function of education is based on the peculiarities, traditions, and educational curriculum of each pesantren.

The next previous study is conducted by Abdul Ghofarrozin and Muhammad Nurul Janah, this research discussed about the theme of measuring state partisanship towards pesantren through the law ratification no. 18 of 2019 resulted in a final conclusion that the legalize of pesantren legislation has five important points that shows a bias against educational pesantren institution. The state provides ease of access and recognition to the existence of the pesantren, providing recognition of the academic tradition of pesantren, still keeping the tradition of pesantren with each characteristic, keeping the position of the pesantren remained independent, as well as maintaining a commitment nationality (Ghofarrozin \& Janah, 2021). It can be concluded from the results of these studies is that the outline of the government through pesantren legislation has a bias proportional to the role of pesantren during this time. Although people in the past considered that pesantren is still known as an institution of traditional education which is far from modernity and have yet to get the attention of the appropriate government.

Previous studies will provide an increasingly comprehensive to find the purpose of the law contained in pesantren's law. Although in glasses of axiology completely different with the research above, but these studies can be the data that support in conducting research. This study will focus on the main theme, which is summed up in the formulation of research problem below.

\section{Results and Discussion}

History of education in Indonesia starts from a private institution, namely pesantren and hermitage. In accordance to what is delivered by the observer of education, Darmaningtyas, quoted from nu.or.id. The role of pesantren in education's world is very large, in addition to have the function of education, pesantren is one of example ways to spread Islam in archipelago. Pesantren has three elements to be interpreted as pesantren, such as students, scholars or teachers, and boarding or 
cottage. Along the way many people interpret the meaning of pesantren with shape of physical building (Saridjo, 1982).

As time passes, pesantren experienced the development and significant growth, so the government took the initiative to set it up with a manifestation of pesantren' law. The presence of education law which is followed by the law no. 55 of 2007 also put pesantren as an educational institution of non-formal Islamic religious. All facts related to institutions of non-formal religious education shows that such recognition has not completely acknowledged the practice of educational pesantren which is implemented in a structured and tiered of the burden of the same learning with general formal education.

Therefore, the governments initiated the text of law about pesantren and religious education on October 16, 2018, President through Ministry of Secretariat State as a letter Number B-9982/M. Sesneg/D-1/HK.00.01/11/2018 November 27, 2018. This letter designates the Minister of Religious affairs as the coordinator to do the preparation of the list of inventory problems (DIM) together with the Minister of Education and Culture, Minister of Research Technology and Higher Education, the Minister of Finance, Minister of Internal Affairs, Minister of State Apparatus Empowerment and Reforms, as well as the Minister of Law and Human Rights (was zayadi, n.d.).

Later in its development, the discussion of pesantren and religious education leads only to discuss about pesantren' law. Officially, list of inventory problem (DIM) and text of law about pesantren is a result of study conducted by several ministries, which is submitted to Parliament on March 25, 2019. The refinement of the jointlyconducted by a team of authors (Timsus) and Synchronization Team (Timsin) of Parliament and Government, based on the inputs from the various elements of society.

After going through various processes, Joko Widodo as the President of Indonesia through presidential decree Number 22/2015, became a full acknowledgement of pesantren existence. Recognition of educational pesantren institution is a form of recognition in their entirety to the pesantren that has existed long before the independence as an educational institution which has a characteristic contribution to the growth and development in Islamic education in Indonesia. 


\section{Understand the Substance of Pesantren's Law}

In efforts to strengthen the faith and devotion and morals, with pesantren trademark made contribution which is significant for the establishment of Islam as the religion of mercy for all people. Pesantren is educational institutions that are about to grow good character, patriotic and a progressive humankind who have proven that they have the spirit of nationalism and role even real actions in a whole independence movement of the unitary state of Indonesia.

Pesantren as a sub-culture, has a characteristic that has been entrenched as well as living and thriving in the midst of community in carrying out the functions of education, the function of propaganda, and the function of community empowerment. Historically, the existence of pesantren become very important in the development efforts of community, especially as derived from the aspirations of community and reflect the needs of community.

To ensure the implementation of pesantren, the necessary arrangements in order to provide recognition, affirmation, and facilities to pesantren by his trademark (Ghofarrozin \& Janah, 2021). Meanwhile, the setting of pesantren is not yet accommodated the development of aspirations and needs of legal community, as well as not put the setting of law in the framework of integrated legislation and comprehensive.

This thing causes legal treatment which is not in accordance with norms based on his trademark and the gap is a great resource in pesantren development. As a strategic part in traditional and cultural richness of Indonesian nation that needs to be maintained by trademark, pesantren should be given the opportunity to thrive, facilitated and improved the quality by all components of nation, including central and local government.

In addition, pesantren's law is expected to meet aspirations development and needs of legal community on aspects such as the recognition of independence of pesantren organization, the recognition of variants and models of pesantren implementation, in recognition of the fulfilment of pesantren elements and the spirit of pesantren as a condition of establishment, recognition to the pesantren education as part of the national education implementation. 
The law of pesantren also became the foundation to give affirmation to the security and quality level of the graduates, the equality of access to education for graduates and equality in employment opportunities. Including the recognition of competence qualification and professionalism of educators and educational staff on pesantren education.

As an effort to create education that is equitable, the regulations no. 18 of 2019 will be a legal basis for instrument funding formation to ensure the availability and fulfilment of the budget in the development of pesantren. Then one of the things that are important to be strengthened is pesantren's law as a legal basis to strengthen the role of pesantren in national development to answer the challenges of the times.

\section{Description of Pesantren's Law}

Pesantren according to Mastuhu is the Institute of traditional Islamic Education to learn, understand, explore, appreciate, and practice the teachings of Islam by emphasizing the importance of religious and moral as the code of conduct day-to-day (Mastuhu, 1994). Other terms of the pesantren is Al-Ma'had which means the campus or location of the place of Education (Zakariyah, 1972). Therefore, in pesantren, the students must stay in the cottage or in the campus area, here they eat together, recitation, chanting, prayer and congregational prayers. In addition, they also follow the instruction regularly after the maghrib, isha, fajr, in the middle of the night they do tahajjud and elsewhere (Karim, 2019).

Word of "pesantren" derives from the root word of santri (students) with the prefix "pe" and the suffix "an" which means the place of students' residences. In addition, the origin of the word pesantren is also called from the combination of the words Sant (good human) with syllable tra (willingly) so that the word pesantren can be defined as "a place of good human education" (Wajoetomo, 1977). In addition, there is also the opinion that the pesantren is derived from the word shastri in Indian languages are the people who know the holy books of Hindu religion, or the expert scholars of Hindu scriptures. Said shastri is derived from the word shastra which means holy books, religious books or knowledge (EL, 1994).

Furthermore, the word of santri (students) derived from the word shastri in Indian languages, means the holy book of Hindu religion with the assimilation of the Indonesian language and to distinguish the understanding, then it known as students. To distinguish this thing, it says as students that have meaning expert in 
the holy book of Islam, which is the terminology of a person who focuses on learning about science of Islamic religion. People who focus explore the science of religion should be serious and settle down at a specific place called the cottage. For serious study at the cottage, there must be ulama (scholars) as the caregiver or spiritual teacher (Dhofier, 2011). That's the hallmark of the pesantren as well as a set with other educational institutions.

Based on the explanation above, pesantren as an Islamic educational institution, have five elements and characterizes of the fundamental, i.e., the cottage, the mosque, the Islamic book, students and scholars. In addition, to the five elements just as the elements of the complement, for example, hall, field, cooperatives, health services and others. In the area of the pesantren there are scholars, the mosque, as well as other buildings such as the class recitation, library, office, canteen and store other supplies.

Pesantren is usually surrounded by a fence or wall to keep out the influx of the students and the guests. Here, students and scholars as well as teachers establish a close relationship, the emphasis on simplicity, sincerity, and mutual help, and sacrifice for the sake of religion, take the time to learn and teach intensively based on the schedule set by the regulations or any other regulations (Karim, 2019).

Meanwhile, according to the law no. 18 of the year 2019 about pesantren in chapter 1 article 1 verse (1): "Pesantren is an institution that is community-based and established individual, foundation, organization of the Islamic society, and/or community that instills faith and piety to God., The pesantren was founded with the purpose to grow good characters as well as to uphold the teachings of Islam that is mercy for all people which is reflected from the attitude of humility, tolerance, balance, moderate, and noble values of the nation of Indonesia through education, Islamic $d a^{\prime} w a h$ (missionary endeavor), leadership, and community empowerment in the framework of the unitary state of the republic of Indonesia (Law Number 18/2019, 2019).

Institutional pesantren is governed by article 1 verse (2) that the mention of "Pesantren education is education which is organized by the formal pesantren and pesantren to develop a curriculum in accordance with the peculiarities of the pesantren based on the kitab kuning (traditional yellow book) or Dirasah Islamiyah with the pattern of Muallimin education (Law Number 18/2019, 2019). About the 
typology in institutional pesantren is also set out in article 5 verse (1) which reads, "The pesantren consists of: a. pesantren provide education in the form of kitab kuning study; b. pesantren provide education in the form of Dirasah Islamiyah with the pattern of Muallimin education; or c. pesantren provide education in the form of more integrated courses with general education" (Law Number 18/2019, 2019).

Educational pesantren in the form of Dirasah Islamiyah with a model of Muallimin education is inclusive education, education that combines the science of religion and general science and comprehensively by combining intra curricular, extracurricular and co-curricular. Evaluation by educators on ongoing basis with the aim to monitor the learning process and the progress of the students. The evaluation by Muadalah unit education performed to assess the achievement of the competence of learners in all subjects and competency of learners at all levels (Musthofa, 2020).

A clause which prove the existence of pesantren peculiarities is a provision of Masyayikh council in quality assurance set out in article 27 of pesantren's law: (1) In the framework of internal quality assurance, the pesantren formed a board of Masyayikh; (2) About Masyayikh referred to in paragraph (1), led by a scholar; (3) the Masyayikh board have the task most little; (a) Develop the pesantren curriculum; (b) Carry out the learning activities; (c) To improve the competence and professionalism of teachers and education personnel; (d) Carry out a test to determine the graduation of students based on predefined quality criteria; and (e) Convey the data of the students who pass to the Masyayikh assembly (Law Number 18/2019, 2019).

\section{Axiological Review of Pesantren's Law}

Axiology is the original word from Greek, i.e. axios that have a sense of worth or reasonable. While the logos which means science. Axiology understood as a theory of value. According to John Sinclair, is closely related to a variety of studies that exist in scientific, social, political, religious and other various fields of science which studied by scientists.

In axiological philosophy or the philosophy of value usually, there are 3 things that become the object of discussion, namely: 1. Ethics that addresses human behavior from the standpoint of good and bad value, or right and wrong. 2 . Aesthetic, discussing something from the point of view about beautiful and not 
beautiful value. 3. Religion, which discuss something from the standpoint of religious values or belief system (Dervish A. Soelaiman, 2019).

In axiology, pesantren is the bases of traditional education culture in Indonesia. Pesantren is the oldest educational institutions in Indonesia, which until this time the learning model in pesantren still retained in the middle of educational modernization (Wiranata, 2019). Therefore, pesantren has the distinction of its own learning model. Pesantren is still quite in demand by Indonesian to study religious as well as become favorite way for parents to entrust their children in studying the yellow book or the science of religion.

In axiological study of pesantren' law, there is a provision of the articles which arrange about establishment of pesantren considered towards beneficial for the sustainability of the pesantren. Anam pointed out, there are at least three benefits about rules for organizing pesantren education, namely: 1) From the point of view of pesantren, the recognition that pesantren as national educational institutions is the same with other public educational institutions, this is a challenge for pesantren to compete with other educational institution in creating the next superior generation; 2) From the side as propaganda, pesantren is an Islamic missionary endeavour centre of a tawassuth (moderate), respecting the tradition of community and foster a love spirit of Indonesia's homeland; and 3) community empowerment, pesantren's law explained that one of pesantren's laws which is very important during this run is a community empowerment (Musthofa, 2020).

If viewed from the side of sociological and anthropological, pesantren should be viewed as alternative educational institutions in Indonesia, but the government still considers educational institution of pesantren with other formal institutions. On the one hand, the government recognizes the quality of pesantren graduates, but on the other hand, pesantrenis still considered not fully recognized as an educational institution (syafe'i, 2017).

Then, after passing the challenge of pesantren's law planning, there is a problem that emerged enactment of pesantren's law. The problems faced by pesantren course very varied, according to Ade Dedi Rohayana in papers represented in students commemoration in 2019 (Rohayana, 2019); the challenge of pesantren after the enactment of pesantren's law is divided into two, there are common and nothing special. The common challenge is a challenge faced by all 
pesantren, and the special challenge is a challenge that will be faced by pesantren depend on readiness of each pesantren.

Common challenges to be faced by pesantren according to Ade Dedi Rohayana located on: 1) a regulation or rule of law, 2) system of quality assurance, 3) demands of competition with other educational institutions. While the special challenges that will be faced by pesantren; 1) related to human resources (HR), 2) learning system (curriculum), 3) system of financial management, and 4) infrastructure facilities of teaching learning.

As a form of challenge and readiness of pesantren after passing the pesantren's law ratification if referring to national education law no. 20 of 2003 Article 30, paragraph 4 of religious educational institute and pesantren which reads "Religious education is in the form of Diniyah Education, pesantren, monastery, pabhaja samanera, and any other formations". If you refer to the article 26 of national education law about system of pesantren included in the category of non-formal education.

Based on description about pesantren's law that has been explained above, then pesantren publishes four grains contained in article 26 of pesantren's law in the verse that explains: first, pesantren's line of non-formal education can text tiered or not tiered. Second, pesantren can issue a status as a graduation at a certain level of education. Third, graduates at the level of pesantren education recognized by the formal education other once you pass the exam organized by educational unit accredited provisions of the legislation. The four graduates of the pesantren to obtain a diploma or equivalent formal education can proceed to the next level on the type of other education (Wiranata, 2019).

The impact of pesantren's law implementations, make pesantren has a bargaining position so that pesantren received more attention from central government and regions, considering the pesantren institution is still seen as an independent institution is not like the other general education. As listed in article 48 paragraph 2 of pesantren's law explained that central government and local government also play a pesantren and give help of funding (Law Number 18/2019, 2019).

Although the process is still reaping the pros and cons, especially in pesantren's institution consider on (Presidential Decree) Number 82 of the year 
2021 about the funding of pesantren implementation. As delivered by caregivers of Tahfidz pesantren \& Tafsir al Badar Bogor, Badrudin Subky said that help from government would eliminate the values in pesantren, such as simplicity (Progress, n.d.).

Help from government or endowment funds as set forth in the regulation of pesantren's law certainly has a huge benefit to the development of pesantren education, but it also has consequences that must be anticipated by the pesantren. The anticipation should be done by a pesantren such as understand the technical disbursement of funds to the process of accountability of the use of funds. However, the positive side obtained would have been very large of its regulations regarding to the policy of the state budget for pesantren (Ghofarrozin \& Janah, 2021): 1) The pesantren has the opportunity in developing itself with funds obtained from government; 2) Pesantren can learn about accounting and accountability as well as a form of accountability of fund management; 3) The pesantren can be more vigilant in receipt of any form of aid money that leads to money laundering than a party is not responsible; 4) Pesantren still have flexibility in the search for funds that are lawful in addition to the help of funds from the government. This as a form of obligations of the government in realizing the benefit of (tashorruful imam 'ala arra'iyyah manutun bil maslahah), that the government should be fair to all levels of society.

So far, pesantren' law that became the foundation of law has given affirmations for the assurance and quality of graduate level education in general, has access and equality in employment opportunities. For that, education policy, which accompanies the legalize of pesantren's law should be a legal basis for the formation of instrument funding to ensure the availability and fulfilment of the budget in pesantren development. If the issue of funding can be answered by education policy, then pesantren's law as the cornerstone of law will be able to strengthen the role of pesantren in national development to answer the challenges of times in the future (Musthofa, 2020).

Next, there is refusal of some organizations, Nahdlatul Ulama particularly related to points contained in pesantren's law, Nahdlatul Ulama worries about some article that allowed the government to intervene in pesantren with specific provisions references of the guidelines and guarantee the pesantren quality (the 
impact of pesantren legislation on Indonesian education system - A Projection, n.d.). Concerns about the intervention of the state that threatens the independence of pesantren as embodied in article 15 towards the law no. 18/2019 which reads "The pesantren carry out the function of education as education provision". many people who think that this law will be a gap for the government to intervene more and more into the deepest space of pesantren.

However, according to Rozin and Jannah, this article is actually nothing to worry about, because the provisions listed in article 15 is not separate with the provisions of article 16, which reads "The pesantren held the function of education is based on the peculiarities, traditions, and educational curriculum each pesantren". The function of pesantren education aimed at forming students who are able to excel and to cope with the times (Ghofarrozin \& Janah, 2021).

The pros and cons in this law certainly very reasonable, but many of its benefits in pesantren education. As an explanation that has been told by Anam above, it was about the benefits of pesantren education. Rozin and Jannah also argue about five points which are important benefits in pesantren's law about understanding the alignments of the state towards educational pesantren institution (Ghofarrozin \& Janah, 2021):

First, the partisanship of the state against pesantren embodied in the law no. $18 / 2019$ seen from the access granted by the government to the pesantren and the recognition of the state against pesantren. Access and the role given by the government as a set forth in the legislation in which that thing fully does not cover: (1) Provide for recognition, affirmation, and facilitation against pesantren based on the distinction; (2) The graduates from pesantren can continue their study in universities as well as graduates from other public institutions, are also equivalent in ease of access in finding work; (3) Give a greater role to pesantren in the fields of religion development, education, and community empowerment.

Second, efforts in improving the quality of students. Reinforcement in the sense that it is the recognition in pesantren' academic tradition. Third; keep peculiarities, not uniformity. The Law Number 18/2019 did not dim the value and excellence that characterize the typical of pesantren. Fourth; maintain independence, not the intervention as feared by some pesantren caretakers. The Law Number 18/2019 not weaken the typical traits of pesantren, should not intervene in the pesantren, 
including the formation of financial pesantren's management and governance. Fifth; keep commitments of nationality. The Law Number 18/2019 prevents about abusing the ideology of radicalism, intolerance and rejection of the nationality consensus in the name of religion.

\section{Conclusion}

In axiological study about pesantren's law, the reasons for the rejection of pesantren's law is not fully justified, both the reasons for the substantial or just an excuse editorial. Some of the provisions in pesantren's law is considered to provide the benefits for pesantren sustainability. Some benefits of its rules in pesantren education implementation, namely: First, the recognition that pesantren as national education institution has the same status with formal education institution outside the pesantren. This opportunity also confirms that pesantren should be prepared to face the competition with other agencies outside the pesantren. Second, in accordance with its main function, pesantren is an Islamic missionary endeavour centre of a moderate (tawassuth), respecting the tradition of community and foster a spirit of love from Indonesian homeland. The emergence of pesantren more provided a wide-open opportunity for pesantren to perform activities of missionary endeavor. Third, with regard to the function of pesantren in the development and empowerment of community, passing the pesantren's law asserts that pesantren has a major role to contribute significantly to the empowerment of community.

\section{Acknowledgment}

This paper and the research behind it would not have been possible without the exceptional support of Department for Research and Community Outreaches (LPPM) IPMAFA Pati. 


\section{Bibliography}

Darwis A. S. (2019). Filsafat Ilmu Pengetahuan. Bandar Publishing.

Dhofier, Z. (2011). Tradisi Pesantren: Studi Pandangan Hidup Kyai dan Visinya Mengenai Masa Depan Indonesia (Sembilan). LP3ES.

EL, D. R. (1994). Ensiklopedi Islam. Ikhtiar Baru Van Hoeve.

Ghofarrozin, A., \& Janah, T. N. (2021). Menakar Keberpihakan Negara terhadap Pesantren melalui Pengesahan UU Nomor 18/2019 tentang Pesantren. Islamic Review: Jurnal Riset Dan Kajian Keislaman, 10(1), 1-18. https://doi.org/10.35878/islamicreview.v10i1.267

Karim, B. A. (2019). Strategi Pembelajaran Kitab Kuning. LPP Unismuh Makassar.

Mahfudh, M. S. (1999). Pesantren Mencari Makna (Pertama). Pustaka Ciganjur.

Mastuhu. (1994). Dinamika Sistem Pendidikan Pesantren (1st ed.). PT Raja Grafindo Persada.

Musthofa, I. (2020). Formulasi Pendidikan Pesantren Dalam UU Nomor 18 Tahun 2019 Tentang Pesantren (Tinjauan Kebijakan Pendidikan). Intizam, 4(1).

PMA No. 18 Tahun 2014 tentang Satuan Pendidikan Muadalah. (2014).

PMA No. 71 Tahun 2015 tentang Ma'had Aly. (2015).

Progres. (n.d.). https://progres.id/featured/

Rohayana, A. D. (2019). Tantangan Dan Peluang Pesantren Pasca Undang-Undang Pesantren. Ponpes Modern Al-Quran Buaran, 1-19.

Saridjo, M. (1982). Sejarah Pondok Pesantren di Indonesia. Dharma Bhakti.

Setyawan, M. A. (2019). UU Pesantren: Local Genius dan Intervensi Negara terhadap Pesantren. MANAGERIA: Jurnal Manajemen Pendidikan Islam, 4(1), 19-40. https://doi.org/10.14421/manageria.2019.41-02

Suriasumantri, J. S. (2005). Filsafat Ilmu Sebuah Pengantaar Populer.

Syafe'i, I. (2017). Pondok pesantren: Lembaga Pendidikan Pembentukan Karakter. Al-Tadzkiyyah: Jurnal Pendidikan Islam, 8(I), 61-82.

Undang-Undang No. 18/2019, (2019).

Wajoetomo. (1977). Perguruan Tinggi Pesantren. Gema Insani Press.

Wiranata, R. R. S. (2019). Rogresivisme: Titik Temu Keabsahan Uu Pesantren Nomor 18 Tahun 2019. Jurnal Komunikasi Dan Pendidikan Islam, 8(2).

Zakariyah, A. Ḥusayn A. I. F. bin. (1972). Mu'jam Maqāyis Al-Lughah. Musthāfā Al-Bāb Al-Halab wa Awladuh.

Zayadi, A. (n.d.). UU Nomor 18 Tahun 2019 tentang Pesantren, Untuk Siapa. https://kemenag.go.id/read/uu-nomor-18-tahun-2019-tentang-pesantrenuntuk-siapa-zeo68 